Running head: Economic Approach to Business Ethics

Review area: Philosophical foundations/corporate governance

Title of paper: An Economic Approach to Business Ethics:

Moral Agency of the Firm and the Enabling and Constraining Effects of Economic Institutions and Interactions in a Market Economy

Author: Dr. Sigmund Wagner-Tsukamoto, Ken Edwards Building, University of Leicester, University Road, Leicester LE1 7RH, UK. Phone: 0116-299 4517. Email: saw14@le.ac.uk

An Economic Approach to Business Ethics: 


\title{
Moral Agency of the Firm and the Enabling and Constraining Effects of Economic Institutions and Interactions in a Market Economy
}

[Key words: Active/passive moral agency, economic viability, ethical capital, incentive ethics, stakeholders]

\begin{abstract}
The paper maps out an alternative to a behavioural (economic) approach to business ethics. Special attention is paid to the fundamental philosophical principle that any moral 'ought' implies a practical 'can', which the paper interprets with regard to the economic viability of moral agency of the firm under the conditions of the market economy, in particular competition. The paper details an economic understanding of business ethics with regard to classical and neoclassical views, on the one hand, and institutional, libertarian thought, on the other hand. Implications are derived regarding unintentional and passive intentional moral agency of the firm. The paper moves on to suggest that moral agency can be economically viable in competitive 'market' interactions, which is conventionally disputed by classical / neo-classical and institutional, libertarian economics. The paper here conceptualises active moral agency of the firm as the utilisation of ethical capital in firm-stakeholder interactions. This yields a reinterpretation of instrumental stakeholder theory.
\end{abstract}




\section{An Economic Approach to Business Ethics:}

\section{Moral Agency of the Firm and the Enabling and Constraining \\ Effects of Economic Institutions and Interactions in a Market}

\section{Economy}

Much contemporary business ethics theory proceeds in a behavioural tradition. For example, virtue theory-based business ethics or Kantian stakeholder management examine corporate moral agency in relation to the question of human nature and proper moral-behavioural conduct of the individual organisation member, in particular managers (Buono and Nichols, 1990; Carroll, 1991; Evans and Freeman, 1993; Preston 1997; Murphy, 1998; Bartlett and Preston 2000; Moore, 2002; see also Barnard, 1958; Etzioni, 1988; Simon, 1993; Küng, 1999; Sacks 1999; Fort, 2000). In practical perspective, behavioural business ethics aim to morally (re)-educate managers, employees, shareholders, etc. (Lampe, 1997; Key, 1997; Seshadri et al., 1997; Hill and Stewart, 1999; Izzo 2000; Siu et al., 2000; von Dran et al., 2001). The goal is to make them less self-interested but more virtuous, altruistic, compassionate, benevolent, and so on.

The present paper outlines a different research agenda for business ethics. It reconstructs corporate moral agency through economic concepts. The paper conceptualises market interactions ('the moves of the game') through a capital utilisation model. Interacting agents are modelled as contributing capital to and receiving capital from exchange interactions. Only if mutual gains and the mutual satisfaction of interests result from capital exchange, is an interaction expected to materialise and to be sustainable over time. The paper interprets economic institutions ('the rules of the game') as incentive structures. Incentive structures influence behaviour by signalling gains and losses, for example business laws on bribery. They 
attach positive or negative sanctions to choice alternatives of the individual agent regarding capital contributed and capital received in economic interactions. Incentive structures make a rational agent choose a certain choice option if gains (losses) expected from that choice option are higher (lower) than gains (losses) expected from alternatives. Many rules of the game are created through legislation ('public ordering'). Only within the confines of public order rules, can firms create ‘own’ rules, through organisational structuring ('private ordering').

The outlined economic approach to moral agency and stakeholder management builds merely heuristically on a model of dilemmatic interest conflicts (Homann, 1994; WagnerTsukamoto, 2003) and on the model of economic man (Hayek, 1949; Friedman, 1953; Becker, 1976; 1993; Homann, 1994; Wagner-Tsukamoto, 2001b; 2003). In certain respects Cima and Schubeck (2001), two Catholic theological researchers, understand this important methodological issue of economic research (For a recent review of this issue, see WagnerTsukamoto, 2003, Chapters 7, 8). The heuristic nature of the ideas 'economic man' and 'dilemmatic interest conflict' are easily misunderstood. If students, managers, consultants or researchers interpret ‘economic man’ and ‘interest conflicts’ in theoretical-practical perspective, e.g. as economics' image of human nature and image of social life or as a behavioural recommendation to act like an economic man or to engage in the escalation of interest conflicts, this needs to be corrected. The correction would be to point out the heuristic, functional nature of these ideas for economic theorising and economic intervention, but not to replace them with concepts of behavioural research. Behavioural business ethics, similar to behavioural economics (Margolis, 1982; Etzioni 1988; Sen, 1987, 1990; Simon 1993), misunderstands the economic approach in this respect when critiquing the model of economic man and the idea of dilemmatic interest conflict in empirical-behavioural and moral-behavioural perspective, even viewing them as the cause of immoral business behaviour. Figure 1 provides a summary of this understanding of the institutional economic approach (See also Wagner-Tsukamoto, 2003). 


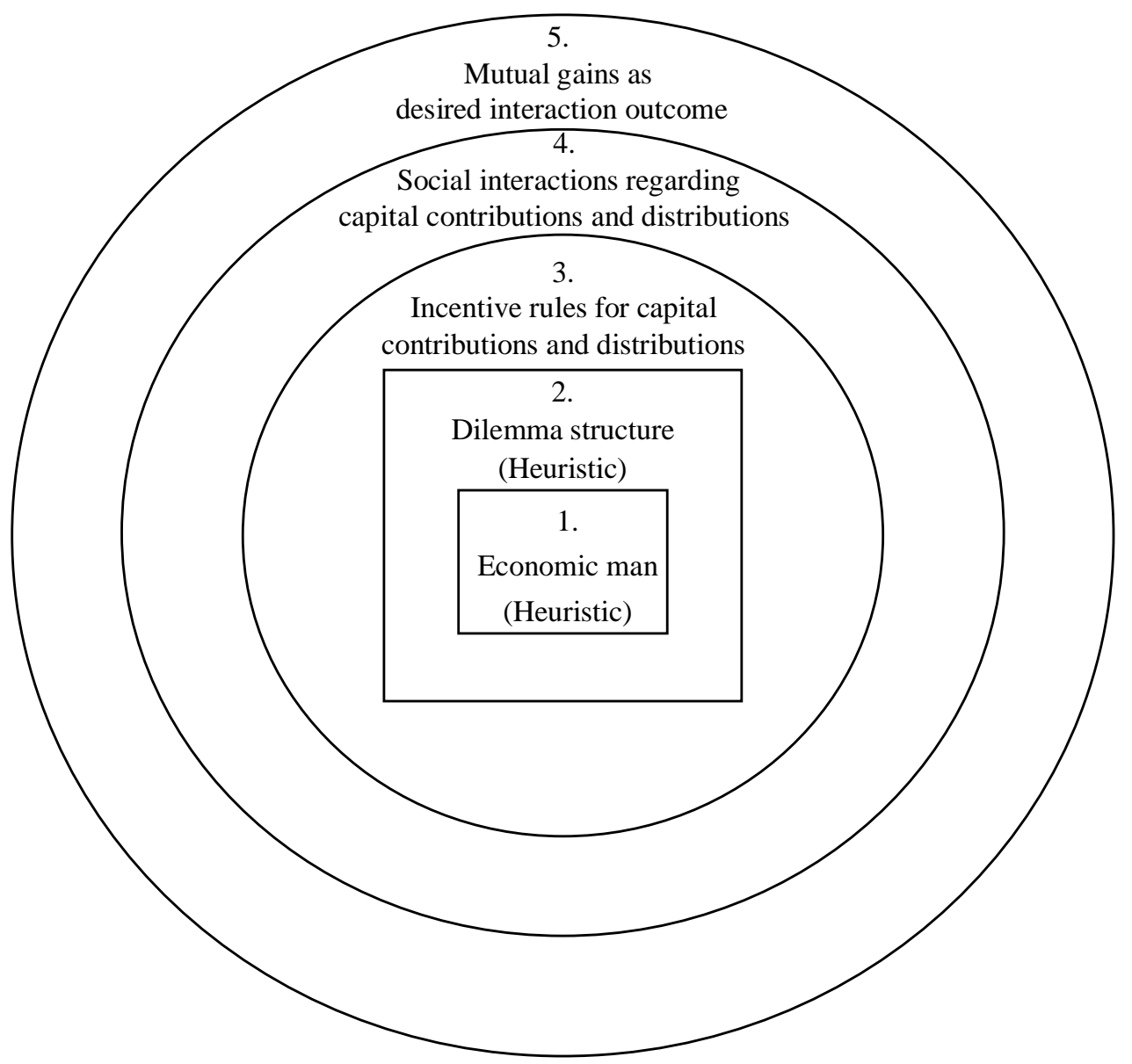

FIGURE 1

The Institutional Economic Approach

The analytical starting point of this paper compares to the usual moral philosophical approach. Ethical doctrines as diverse as virtue ethics, duty ethics or consequentialism subscribe to the principle that a person is expected to abide only by a moral precept if he/she has the required capabilities to do so. For instance, when a non-swimmer falls into deep water 
and is drowning, a bystander is expected to jump into the water and save the non-swimmer but only if the bystander can swim. A moral ought ('moral responsibility') always implies a practical can ('competence'). The paper argues that this consideration has far reaching implications for the question of corporate moral agency that behavioural business ethics tend to overlook. As far as corporate behavioural business ethics consider this principle, they predominantly do so in a behavioural spirit, identifying, in the tradition of Kohlberg, the lack of cognitive moral development of managers as a cause of inadequate corporate moral agency, for example Preston (1997), Bartlett and Preston (2000) or Izzo (2000). The present paper examines constraints other than behavioural on moral agency of the firm. The key thesis is that constraining and enabling economic effects on moral agency, as exerted by the incentive logic of economic institutions and the capital exchange logic of economic interactions, need to be considered for ensuring successful moral-behavioural intervention, e.g. ethics education for managers. Otherwise, behavioural business ethics programs only succeed in a sporadic, accidental, and temporary manner, namely as long as moral-behavioural intervention is compatible with economic effects.

The paper suggests to theoretically model and practically intervene with corporate moral agency in relation to the systemising of morality in incentive structures and the capitalising of morality in firm-stakeholder interactions. The paper argues that in this way a theoretically more coherent approach to business ethics and stakeholder management emerges than a moral-behavioural one and that economic intervention is practically more effective than behavioural intervention, especially under the competitive conditions of the market economy and of the modern, pluralistic society in general.

In Part I, the paper takes up the classical and neo-classical view, which points out a moral quality of competitive market ordering. The related concept of unintentional corporate moral agency is spelled out. This is important since the paper examines moral agency of the firm by 
taking for granted the concept of the market economy, especially the endorsement and enactment of competitive market ordering through public order rules. Most behavioural business ethics research, if I interpret correctly, accepts this, too, although, behavioural research implicitly and unwittingly drifts often into a system critique of the market economy, namely when it questions competitive market ordering as the interaction mechanism and self-interest as driving force of social exchange. System exit or system change could then be elaborated on. System exit may imply the retreat into localised markets and small, self-sufficient communities where membership is restricted - probably in an anti-pluralistic, tribal, pre-modern manner - to those who share same beliefs, that is where group membership is linked to a value consensus. The Amish people’s religious fundamentalism or certain ecotopian concepts are illustrative. More radically, if system change is advocated, system alternatives have to be outlined. Since the fading of communism, however, there seem to be few credible alternatives to organising societal interactions in a different way than through a market economy. Reasons for the failure of communism, such as anti-pluralistic tendencies and systemic defects regarding the effective and efficient organisation of economic activity in society, hold important lessons for business ethics theory which explicitly or implicitly advocates system change (Hayek 1960, 1979).

In Part II, the paper takes an institutional, libertarian approach to economics, which assesses institutional structures (the rules of the game) for constraining economic effects on corporate moral agency, e.g. the institutional enactment of profitability as a survival requirement for the firm and of competition as a mechanism for ordering social interactions, e.g. through business laws such as bankruptcy laws, anti-trust laws, etc. The paper specifies here corporate moral agency as passive intentional agency in relation to moral minimum standards that are economically enacted through public ordering. In relation to such institutional structures, the paper discusses nature, feasibility and scope of systemically enabled moral agency of the firm. This details the conventional economic understanding of 
business ethics that market interactions (the moves of the game) regarding capital exchange occur and should occur in a moral-free zone (Hayek, 1960; Friedman, 1970; Smith, 1976; Hayek, 1979). The discussion of passive moral agency further develops suggestions on ‘incentive ethics’ (Homann, 1997).

In Part III, the paper analyses interactions (the moves of the game) for constraining / enabling effects on corporate moral agency, specifically the lack / availability of ethical capital in firm-stakeholder interactions. The paper questions in this respect a sceptical stance of classical and neo-classical economics as well as institutional, libertarian approaches that, apart from unintentional and passive moral agency, corporate moral agency is not economically viable in market interactions and even undermines unintentional and passive moral agency. The paper models active moral agency of the firm as the utilisation of ethical capital in firm-stakeholder interactions. It suggests that once morality is transformed into an economic asset, corporate moral agency yields competitive advantage, increases profitability and increases survival prospects of the firm. In this respect, insufficient corporate moral agency is analysed not as a systemic, rule-based condition of defective incentive structures but as a capital utilisation problem in firm-stakeholder interactions.

Thus when the paper moves from Part I to Part II and then to Part III, a dichotomised view on business ethics and economics is questioned step-by-step and further revised.

\section{The Classical and Neo-classical View: Competitive Market Ordering and the Elimination of Morals from Economic Interactions}

Economic institutions of the market economy make firm survival directly dependent on profitability but not on the extent of moral agency shown in interactions with other firms, 
customers, suppliers, society at large, etc. ${ }^{1}$ The sociologist Max Weber realised this early on when stating in his famous treatise The Protestant Ethic and the Spirit of Capitalism:

It [the capitalistic economy] forces the individual, in so far as he is involved in the system of market relationships, to conform to capitalistic rules of action. The manufacturer who in the long run acts counter to these norms, will just as inevitably be eliminated from the economic scene as the worker who cannot adapt himself to them will be thrown into the streets without a job. (Weber, 1930, pp. 54-5)

And:

Whoever does not adapt his manner of life to the conditions of capitalistic success must go under, or at least cannot rise. (Weber, 1930, p. 72)

In this regard, the costs of moral agency have to be considered for understanding why moral agency is difficult to pursue by the firm. If moral agency is costly and unprofitable, a firm suffers survival disadvantages in comparison to 'less moral' firms. Then, competitive market ordering instigates interaction dynamics which eliminate morals from the moves of the game. ${ }^{2}$ Over time, moral firms are driven out of the market and the moral conscience of managers is selfeliminating (Hardin, 1968; Homann, 1997; Gambetta, 1988; Good, 1988). The eventual failures of charitable religious owner-managers, such as Quaker employers, is insightful here since the sincerity and depth of their moral convictions may be less questioned than the ones of 'plain', professional managers (Wagner-Tsukamoto, 2001b, 2003).

A. Unintentional Moral Agency of the Firm: The 'Wealth of Nations' as Moral Outcome 
Since competitive market ordering can punish costly moral agency of the firm, one might be tempted to judge the competitive market as immoral, both regarding outcomes of social interactions - the constraining and eliminating of corporate moral agency in market interactions - and regarding the self-interested image of human nature that it seemingly implies. Behavioural business ethics and behavioural economics voice such concerns (Etzioni, 1988; Sen, 1990; Simon, 1993; Bartlett and Preston, 2000). The moral legitimacy of the market economy can then be questioned and system change can be advocated, aiming to replace competition as the interaction and co-ordination mechanism of economic activity.

Classical and neo-classical economics agrees with the diagnosis that competitive market ordering may undermine moral agency. It views corporate moral agency as infeasible in the moves of the game. Market ordering itself is thought to best occur in a moral-free zone (apart from moral standards enacted through public ordering; see below). This was implied by Smith, prominently restated by Hayek and Friedman, and further detailed by Buchanan and North (Hayek, 1960, 1976, 1979; Friedman, 1970; Buchanan, 1975; Smith, 1976; North, 1993b; see also Popper, 1962). But in this understanding of economics, the elimination of moral agency from the moves of the game does not necessarily constitute a moral problem. The opposite can be the case. Economics argues for competitive market ordering on moral grounds. This is based on the expectation that competitive market ordering yields desirable outcomes for society as a whole - the 'wealth of nations', as Smith put it - but not the wealth of a few (Wagner-Tsukamoto, 2003, Section 8.1). Indeed, if Adam Smith's outline of economics did not reflect a moral science, it would be difficult to comprehend why Smith, after decades of behavioural ethics research and on the basis of a profound understanding of behavioural ethics, ultimately favored economics to address moral questions of society.

The studies of Hayek, Friedman, Buchanan and North argued in detail that the market economy delivers prosperity, fairness and liberty in societal interactions better than other 
doctrines, e.g. communism. Once the market economy produces socially desirable outcomes, the firm is involved in moral agency, namely unintentional moral agency (Homann, 1997; Homann and Suchanek, 2000; see also Baurmann and Kliemt, 1995). Only on this ground can classical and neo-classical economic theses on business ethics be justified: see, for example, 'The Social Responsibility of Business is to Increase its Profits.' (Friedman, 1970)

These considerations mark an important starting point for assessing the moral legitimacy of the market economy and the question of business ethics. Behavioural ethics here tends to struggle with the implied conceptualisation of moral agency as unintended result of selfinterested choice, and the morally argued endorsement of competition, which implies non-cooperation in interactions among firms (Wagner-Tsukamoto, 2001b).

In this connection it is important to note that it is the very conception and endorsement of competition as an interaction mechanism that enables economics to conceptually and practically accommodate value pluralism in social interactions. Such accommodation is important since pluralism can be viewed as a socially desirable interaction condition. But, anyway, in many interaction contexts pluralism is an unavoidable interaction condition. These are contexts which are defined by competitive market ordering and the political-legal institutionalisation of the market economy as well as by industrialisation, the growth of societies, urbanisation, and internationalisation and globalisation. In such 'modern' contexts, ${ }^{3}$ the theoretical fruitfulness, practical effectiveness, moral relevance, and moral quality of behavioural ethics, which build on the vision of an anti-pluralistic value consensus, are in doubt. ${ }^{4}$ An important thesis here is that for ethical and effective intervention in social interactions in a large city, the multi-national firm, the multi-cultural society, global markets, or the international community, an economic approach to (business) ethics has to be prioritised over a behavioural one. 


\section{B. Slack as Enabler of Corporate Moral Agency?}

When considering competitive market ordering, a ‘slack-based' argumentation for business ethics (Buono and Nichols, 1990; see also Etzioni, 1988; Simon, 1993) has to be qualified. A slack-based approach to business ethics proposes corporate altruism and corporate philanthropy, suggesting that a firm should spend 'slack resources', such as profits, on ethical courses, such as philanthropy. ${ }^{5}$ The idea of slack implies economic competence and opportunity of the firm to engage in moral agency. However, in competitive markets, slack-based business ethics are likely to run into problems. Moral firms which spend slack on altruistic causes have fewer resources available than less moral firms when preparing for survival, e.g. buffering a firm against uncertain, future market developments, making R\&D investments into the generation of future market opportunities, and so on. Hence they are disadvantaged in competitive processes. Both Weber (1930) and Friedman (1970) implied this. Also, a slack-based conceptualisation of corporate moral agency implies that firms would only engage in moral agency if slack existed. When competition toughens and survival conditions deteriorate, costly moral agency is disposed of. Thus, business ethics become not a categorical but a hypothetical, highly conditioned endeavour, relying on the existence of uncompetitive and highly imperfect markets. For a motive ethics such as a religious ethics, a virtue ethics, or duty ethics, this approach to moral agency is likely to lead to considerable conceptual inconsistencies since motives are no longer grounded in categorical precepts. And, practically this leaves the virtuous, religious or dutiful manager with severe conflicts of conscience and awkward decision-making regarding how to retreat from moral agency when the going gets tough (Wagner-Tsukamoto, 2001b).

The argument that competitive market ordering undermines moral agency, as implied by the argument of slack, can be revised in various respects. For one thing, if corporate moral agency were less costly than 'non-moral' agency, competitive market ordering can be expected 
to almost automatically moralise corporate behaviour. But in this case, there is not much debate about business ethics. The remainder of this paper discusses different qualifications of the classical and neo-classical suggestion that competitive market ordering eliminates moral agency from economic interactions. The paper argues that in certain circumstances the cost of moral agency does not disadvantage a firm in processes of competitive market ordering. The underlying assumption is the one of competitive markets. This is a much weaker assumption than perfect competition of general equilibrium theory. On the one hand, through public ordering, corporate moral agency can be systemically enforced through the institutional rules of the market economy. Thus, the same costs of moral agency are imposed on all firms. Hence, the cost of moral agency is competition neutral. In this respect, Part II of this paper details the concept of systemically enabled passive moral agency of the firm. In Part III, the paper looks into the profitability of business ethics. If corporate moral agency creates revenue which covers costs of moral agency, then (and only then) moral agency is sustainable in the moves of the game beyond moral standards enforced through public ordering. The paper discusses the profitability of moral agency as active moral agency. The idea of ethical capital is spelled out. It implies that market segments of ethically committed stakeholders of the firm are willing to pay costs of active moral agency and thus create additional revenue for moral firms. In this respect the paper overcomes the classical and neo-classical dichotomy of economics versus ethics regarding market interactions.

II. A Libertarian, Institutional Economic View: Passive Corporate Moral Agency and Enacting the 'Moral Minimum’ Through Public Order Structures 
Incentive structures induce rule-following on grounds of self-interested choice. Buchanan's and Williamson's insights here can be transferred to an economic analysis of moral agency of the firm. Buchanan conceptualised public order structures, e.g. laws, as incentive structures while Williamson’s institutional economics similarly examined organisational, 'private order' structures of the firm, e.g. reward systems. (Buchanan, 1975, 1987a, 1987b, 1991; Williamson, 1985; Brennan and Buchanan 1986). As Buchanan specified, for public order structures to be effective, expected gains from breaking a rule have to be lower than expected losses (See also Becker 1976, 1993; Vanberg, 1988, 2001; North, 1993a, 1993b), or differently put, rulefollowing has to be compatible with self-interest. ${ }^{6}$ On the other hand, if expected losses from breaking a public order rule are outweighed by expected gains, an agent can be expected to break public order rules. In this way, public ordering is brought under an economic calculus for the firm, a calculus of competitive advantage, profitability and survival. Regarding corporate moral agency, public order structures are a means to systemically codify moral precepts (in laws, in the rules of the game) and arm codifications with economic and criminal sanctions. Thus, moralbehavioural rules are systemised in economic terms. Then, incentive structures systemically enable moral agency (Homann, 1997; Homann and Suchanek, 2000). In this respect, public ordering creates social capital, that is, it reflects investments of the past enforcement of moral rules (Vanberg, 1988, p. 33).

With regard to the enforced and indirect nature of corporate moral agency that is so enacted through public ordering, the idea of passive moral agency can be invoked. From a teleological, consequentialist point of view (but less so from a deontological position), it can be examined how far such passive moral agency of the firm can be considered intentional moral agency.

A key strength of enforcing moral agency through public ordering is that it is competition neutral: It imposes the same sanctions and the same costs for moral agency on all firms. Thus, 
public ordering creates a level playing field regarding costs of moral agency. Public ordering has in this respect the advantage over private ordering. A good example is reward structures of the firm which allocate bonuses to salesmen in relation to sales volume but independent of moral assessments of how sales were generated, e.g. through corruption or bribery. Frequently, such problems cannot be resolved by private ordering, e.g. the inclusion of business ethics rules in a corporate mission statement (even if violations of rules were effectively sanctioned by the firm). The reason is that costly sanctions voluntarily imposed by the firm for moral misconduct of its members are not competition neutral. If they lead to lower profits and competitive disadvantages, the scope for enacting moral agency through private ordering is limited.

But there are also limits to which morality can be economically systemised through public ordering, even if public ordering comes with economically effective sanctions. For incentive structures to induce and organise social exchange, outcomes of choice behaviour have to be generally advantageous to all involved in an interaction. Mutual gains have to result. Williamson (1985, p. 76) speaks here of the ‘incentive-compatibility’ of governance structures. Public order structures which systemise moral agency in a confiscatory, 'communist' manner, e.g. taxing corporate profits at a 85 percentage-rate, are likely to be ineffective since they eliminate private gains and self-interest as the co-ordination force of social interactions. In this case, rules become 'dis-incentive structures', even undermining outcomes of unintentional moral agency. It appears that public ordering can only effectively enforce moral minimum standards. It needs to leave the market mechanism intact.

Furthermore, the systemising of morality in public order structures is constrained by the internationalisation of markets. On global markets, the effectiveness of public ordering is potentially eroded from outside national markets (Vanberg 2001). Elimination forces, as discussed for moral private ordering in relation to market ordering, can be observed for public ordering in relation to international market ordering. One nation's lower, less costly 
public order standards regarding corporate moral agency undermine higher, more costly standards of other nations. Market dynamics based on ethical stakeholder behaviour, as discussed below as 'active moral agency', can to a certain extent protect a national market from less moral, international competition. The argument regarding the erosion of moral standards on national markets can also be qualified in relation to existing productivity differentials, differentials in capital structures, transaction costs and relocation costs, etc. Yet, on many competitive, international markets, the playing field with the lowest, least costly moral rules tends to constrain other regulators, unless protectionist measures are taken that directly intervene in the moves of the game and restrict market access. Such restrictions, however, can undermine socially desirable outcomes regarding unintentional moral agency, such as the wealth of nations. ${ }^{7}$

\section{Revisions to the Classical /Neo-classical and Institutional, Libertarian View: Active Corporate Moral Agency and the 'Capitalising' of Morality in Economic Interactions}

There is empirical evidence that corporate moral agency is feasible in the moves of the game, exceeding in a sustainable manner moral minimum standards of public ordering and being viable under competitive conditions of the market economy (Wagner, 1997; Dunfee 1998):

- Environmentally-oriented shopping. Driven by green consumer behaviour and green pressure group campaigns, environmentally-oriented shopping has affected corporate behaviour. For example, the Body Shop has built a multinational enterprise by producing 
and retailing products which are environmentally friendlier than competitor products. Shell's Brent Spar experience is another example in the opposite direction.

- Animal welfare issues. Some consumers take account of animal welfare issues when making a buying decision. For example, they consider whether product ingredients have been tested on animals. Such consumer behaviour had a considerable impact on firms, e.g. producers and retailers of cosmetics.

- Fair Trading with Third World Farmers. So-called fair-traded products, e.g. Cafe Direct, are retailed at a price premium in order to cover higher sourcing prices paid to farmers in developing countries.

In these examples, firms engage in a sustainable manner in corporate moral agency that exceeds moral minimum standards of public ordering. Apparently, the managers of the Body Shop, Shell, or Café Direct have different experiences regarding the feasibility of moral agency under conditions of competitive market ordering than did Quaker managers or other early factory managers (Wagner-Tsukamoto, 2001b, forthcoming; see also Child, 1964; Taylor, 1964). Hence, the conventional economic view that corporate moral agency can only come as unintentional agency or at best as passive, intentional agency needs certain revisions. The paper develops such revisions within an economic framework, outlining a 'third' route of a 'practical can' of corporate moral agency. It models active moral agency: the firm enacting in the moves of the game moral standards that exceed the ones of public ordering. The idea of ethical capital is drawn upon for conceptualising the profitability of corporate moral agency. The paper thus examines whether costs of moral agency can be recouped from stakeholders who exchange 
capital with a firm. An economic business ethics theory is arrived at, which connects to a consequentialist, utilitarian interpretation of instrumental stakeholder management.

In a pluralistic tradition, the proposed theory leaves the conceptualisation of moral dispositions of stakeholders open, e.g. whether they were virtuous stakeholders, dutiful stakeholders, religious or consequentialist stakeholders. ${ }^{8}$

The present paper departs from behavioural economic approaches (Gauthier, 1986; Sen, 1990; Simon, 1993; Baurmann and Kliemt, 1995) but also from evolutionary economic approaches (Axelrod, 1984) to conceptualising (corporate) morality in the moves of the game. They expect contractual and/or behavioural self-binding to emerge over time. Thus, moral agency in these approaches is viewed as an exchange catalyst but moral agency is not the subject of capital exchange. In this respect, the paper diverts from a virtue economics and an evolutionary economics. It conceptualises moral agency as (the utilisation of) production capital, which is sold or bought in market interactions, but not as transaction capital, which may help to stabilise market interactions (assuming effective self-binding).

\section{A. Ethical Capital}

For an economic reconstruction of corporate moral agency, the Body Shop presents an especially interesting case study. Many observers of the Body Shop agree that the Body Shop is 'more moral' than other firms (in its industry). Since the Body Shop has survived very well over time, despite costly engagements in moral agency, this requires an economic explanation; otherwise the value of an economic reconstruction of business ethics can be doubted. Rather than drawing on the argument of 'slack', I assess such firms as creators of ethical capital which is profitably 
exchanged with interested stakeholders (operating in competitive markets, where also 'less moral' firms are encountered, which do not engage in costly, voluntary business ethics).

Only as long as the firm cannot recoup costs of moral agency from consumers, employees, investors or other agents ('stakeholders', see below) who interact with the firm, do profitability and related survival issues constrain moral agency to unintentional agency and passive agency. As discussed, the latter reflects the abeyance of moral minimum standards that are enforced by public ordering (effective economic sanctioning of public ordering assumed). On the other hand, if corporate moral agency contributes to profitability and creates survival advantages, the conventional economic view, as outlined in Parts I and II, that market ordering occurs in a moral-free zone can be qualified. Such corporate moral agency can be termed active moral agency. It can be conceptualised through a capital utilisation model of social exchange. ${ }^{9}$ Agents who interact with the firm are modelled as capitalists who contribute resources to and receive resources from exchange interactions with the firm. If an agent uses capital to enact ethical interests, the firm gains or loses in interactions with such agents, depending on whether the firm successfully satisfied moral interests of these agents. Thus morally minded agents can enable economic competence of the firm to engage in moral agency beyond unintentional and passive agency.

In this conceptualisation of active corporate moral agency, morality is approached as an economic asset, as ethical capital. Ethical capital reflects the 'price' a morally minded consumer, employee, investor or other agent puts on active moral agency. It indicates an agent's economic willingness and resourcefulness to pay for active moral agency of the firm. The idea of ethical capital thus specifies what Dunfee (1998, p. 128) described as a ‘... decision with an economic impact influenced by a passion of propriety' that reflects 'an input into the marketplace of morality.' The idea of ethical capital implies that the question of business ethics is examined in the same way as questions of how a firm successfully buys, 
creates, sells - utilises - commodities such as human capital, technological capital, brand capital, site-specific capital, etc. Regarding its intangible nature, ethical capital compares to intellectual human capital (Becker, 1976, 1996), social capital (Coleman, 1988; Vanberg 1988) or brand equity (e.g. Aacker, 1991). Such capital reflects the economic valuation of psychological or sociological features of products and services.

Active moral agency of the firm and the creation of ethical capital can be initiated by (the managers of) the firm. The firm can produce ethical capital by utilising, for example, production processes and distribution processes in ways that surpass moral minimum standards of public ordering and/or which outperform competitor behaviour regarding moral agency. In the above mentioned examples of the Body Shop or Café Direct, it was the firm that successfully nourished a market segment of ethically committed and economically resourceful agents, e.g. green consumers. In this regard, private ordering can 'moralise' market ordering. Another example is corporate social initiatives which can set up economic pay-offs (Hess et al., 2002). Charity shops, e.g. Oxfam, are further examples of organisations that actively built and anticipated ethical preferences of consumers and transformed them into economic assets. Albeit using a different approach, Frank’s (1996) discussion of market opportunities created by ethical business behaviour moves into a similar direction.

On the other hand, market ordering can 'moralise’ private ordering. Active corporate moral agency can be initiated by resourceful agents who interact with the firm and back up moral interests with capital. For example, a firm may have to follow market demand of morally highminded, green consumers who are willing to pay a price premium for environmentally friendlier products. A good example is the cosmetics industry, in which the Body Shop's successful catering for ethical consumers had over time a considerable impact on other firms. The government or the judiciary can in this way enact active corporate moral agency, too, for example in relation to discretionary powers they enjoy regarding the setting of fines, making 
changes to taxation, etc. For example, in US-jurisdiction, courts frequently decide the extent of penalties by considering a firm's ethical track record, e.g. the treatment of employees, sponsorship of cultural events, support given to local communities, donations to environmental causes, etc. Thus, an economic pay-off-rationale for active moral agency of the firm is established.

More drastic examples are consumer boycotts organised by pressure groups (Smith, 1990). A consumer boycott has a similar enabling effect on active moral agency as consumer demand for ethical products and services. A pressure group which successfully organises a consumer boycott in effect appropriates market capitalisation of the firm, e.g. market share and sales volume. Such influence is exerted through any stakeholder boycott. For example, a strike organised by a union has a similar effect (see below). Once appropriated, market capitalisation is redistributed to other firms or is just destroyed. Shell's Brent Spar experience is a classic example. Although a pressure group does not directly exchange capital with a firm (unless being an employee, shareholder, or customers at the same time), it can influence capital dispositions of other agents who interact with the firm. Such influence reflects the capability of a pressure group to intervene in market ordering. This may be equally effective or even more effective than direct capital exchange with the firm since the impact on the firm can be quickly multiplied (once a boycott catches on), is immediate, unexpected and more difficult to counteract by the firm.

B. Towards an Economic Theory of Business Ethics: Stakeholders and the Demand for Ethical Capital

The following section links the concepts of ethical capital and active corporate moral agency to an economic interpretation of stakeholder management. In the 1960s, the Stanford Research 
Institute (SRI) interpreted the idea of the stake as an interest of an agent ('stakeholder') who can influence, through economic dispositions, the profitability and survival prospects of the firm (Freeman, 1984). Drawing on the above capital utilisation model of social exchange, the idea of the stake can be specified as interests that are backed by capital contributions of an agent. ${ }^{10}$ In this way, stakeholder management is instrumentally approached in relation to the capability of an agent to influence the firm's profitability and survival prospects through capital dispositions. On the other hand, if an agent cannot contribute capital of one form or another to the firm, he/she does not qualify as a stakeholder. On economic grounds, the firm would not be expected to take account of his/her interests.

On the basis of a capital utilisation model of stakeholder management, the question of active moral agency of the firm can be more precisely formulated. ${ }^{11}$ Low levels of active corporate moral agency are theoretically analysed and practically intervened in as a capital utilisation problem, specifically as a problem of inadequate demand for ethical capital by stakeholders. The resulting model of stakeholder management is an instrumental one. It differs from conventional, behavioural approaches to stakeholder management and business ethics. Most importantly, an instrumental, economic approach to stakeholder management takes account of the economic viability of corporate moral agency under the conditions of the market economy. The principle that a 'moral ought' implies a 'practical can' is thus paid attention to. Specifically:

- The outlined economic approach to stakeholder management models active moral agency in a strictly hypothetical manner: namely, in relation to the profitable production of ethical capital for morally high-minded and economically resourceful stakeholders. In this respect, it differs from virtue theory or Kantian stakeholder models. The latter imply a categorical approach to stakeholder management, which reflects their less specific interpretation of the 'stake' as a mere interest of an agent, independent of the assessment 
of capital contributions an agent is capable and willing to make to the firm. A pay-off rationale for corporate moral agency is not conceptualised, thus abandoning the SRI understanding of the ‘stake’ (e.g. Buono and Nichols, 1990; Evans and Freeman, 1993). Also, the outlined approach conceptualises the hypothetical nature of moral agency differently than, for example, a slack-based approach to business ethics, which hypothetically models moral agency as the spending of available profits on altruistic causes.

- The question of moral responsibility of the firm is redirected. In the first place, stakeholders are asked this question. Only on the basis of willingness and resourcefulness of stakeholders to pay for active corporate moral agency, is the question of business ethics handed to the firm.

- The resolution of stakeholder conflicts is brought under an economic calculus. Conflicting stakeholder interests are prioritised in relation to the extent that an agent can influence the profitability and survival of the firm. In contrast, behavioural stakeholder management tends to suggest that the firm should resolve interest conflicts among stakeholders in an egalitarian manner, taking equal account of all interests. Basically, moral agency by means of consensus management is promoted. Kantian stakeholder management or a slack-based approach face in this respect unresolved practical problems to reconcile the satisfaction of diverse, conflicting stakeholder interests with the maintenance of economic viability of the firm.

- The proposed economic approach to stakeholder management examines the legitimisation of corporate behaviour, and of the market economy in general, in relation 
to socially desirable outcomes of firm-stakeholder interactions, idealistically mutual gains that include the stakeholder global community. To a degree, the resulting legitimisation of corporate behaviour and of the market economy can accommodate a behavioural approach, e.g. a sociological argumentation for consumer sovereignty and consumer democracy (Cochran, 1957). However, in various methodological, theoretical, and practical-normative respects reconciliation may be difficult, and the prioritising of an economic approach over behavioural ones becomes an issue.

Future research has to further deepen these key ideas of an economic approach to stakeholder management. The previous discussion provided only a first step to a fuller reinterpretation of interrelationships among economics, ethics and stakeholder theory.

\section{Conclusion}

Similar to Adam Smith two centuries earlier, moral philosophers of our time, like MacIntyre (1985) diagnosed that modern society may have to ask what comes After Virtue. (See also Williams, 1985.) Such scepticism regarding the effectiveness of behavioural ethics, especially in modern, pluralistic contexts, is shared by economic philosophy (Buchanan 1975, 1987b, 1991; Homann, 1990, 1994,1997), systemic sociology of society (Luhmann, 1984, 1988), and Old Testament theology (Wagner, 2000; Wagner-Tsukamoto, 2001a). An economic approach to business ethics can theoretically and practically handle an After Virtue-scenario, mainly because it does not rely on the homogeneity of moral values, virtues, religious beliefs, etc. when examining the effectiveness of moral agency in group behaviour. This is due to its nonbehavioural conceptualisation of corporate moral agency in relation to economic institutions and 
economic interactions. Economic intervention strictly aims at incentive structures and capital utilisation but not the human condition in order to raise levels of corporate moral agency. From a heuristic perspective, this is mirrored by the application of the model of economic man and the idea of dilemmatic interest conflicts (see Figure 1). Under conditions of competitive market ordering and/or value pluralism, this approach is likely to be more effective and even preferable on ethical grounds to behavioural ethics.

The paper has modelled interrelating economic effects of public ordering, market ordering, and private ordering in order to examine how moral agency of the firm is economically enabled and constrained. The paper has drawn attention to the classical economic idea of unintentional moral agency of the firm, which justifies the moral legitimacy of the market economy. Intentional, passive moral agency has been discussed regarding moral minimum standards that are economically enforced by public ordering. The paper has conceptualised intentional, active moral agency of the firm by drawing the idea of ethical capital and an economic interpretation of stakeholder management. It has tightened the idea of the stake, interpreting 'stake' as an interest that is backed by capital contributions to the firm. The stakeholder has been examined for willingness to pay for active moral agency of the firm. The successful enactment of moral interests of stakeholders has been assessed in relation to the creation and utilisation of ethical capital in firm-stakeholder interactions.

Regarding active moral agency, the proposed economic approach to business ethics qualifies conventional economic thought that corporate moral agency is limited to passive and unintentional moral agency and that active moral agency is detrimental to profitability and survival prospects of the firm. In (niche) markets where economically resourceful, morally highminded agents are encountered, firm-stakeholder interactions do not occur in a moral-free zone (that is 'only' regulated by public order standards). ${ }^{12}$ Through private ordering, a firm and its stakeholders can enact moral standards that surpass moral minimum standards enforced by 
public ordering. In order for private ordering to successfully enact such moral standards, the paper has argued that private ordering has to be compatible with market ordering, namely the incentive logic and the capital exchange logic of competitive markets (and it has to be compatible with public ordering in this respect, too, namely rules which enforce competitive market ordering through cartel laws, anti-trust laws, bankruptcy laws, price dumping laws, etc).

The outlined economic reconstruction of business ethics theory sheds new light on previously inconclusive, empirical research on the feasibility and profitability of behavioural business ethics, as recently reviewed by Bartlett and Preston (2000) and Moore and Robson (2002). Conceptual and practical problems and empirical inconclusiveness of research can be predicted for behavioural business ethics if corporate moral agency is not investigated for constraining and enabling incentive effects of public ordering, market ordering and private ordering and the utilisation of ethical capital in firm-stakeholder interactions. Once these issues are considered, the practical success or failure of behavioural business ethics can be predicted on the basis of compatibility or incompatibility with profitability and survival requirements of the firm.

The paper has demonstrated that corporate moral agency can be differently assessed other than by interpreting in behavioural terms the question of human nature and the principle that a 'moral ought' implies a 'practical can'. The paper has shown three routes of how to interpret a 'practical can' in economic terms through concepts of unintentional moral agency, intentioned passive agency and active moral agency. It has thus spelled out various conceptual dimensions that put the debate of business ethics theory into perspective. However, the paper has not generally questioned the relevance of behavioural ethics; especially for the ethical education of stakeholders its relevance is high. Nor does this paper question that a certain minimum consensus of shared behavioural categories is likely to be required for any social interaction to succeed (Luhmann, 1984, 1988; Good, 1988). Nevertheless, many behavioural researchers and 
theologians underestimate the extent to which the moral agency of the firm can be reconstructed and practically handled in economic terms. 


\section{REFERENCES}

Aaker, D. A.: 1991, Managing Brand Equity: Capitalizing on the Value of a Brand Name (Simon \& Schuster, New York).

Axelrod, R.: 1984. The Evolution of Cooperation (Basic Books, London).

Barnard, C.: 1958, 'Elementary Conditions of Business Morals,' California Management Review 1(1), 1-13.

Bartlett, A. and D. Preston: 2000, ‘Can Ethical Behaviour Really Exist in Business?,’ Journal of Business Ethics 23 (2), 199-210.

Baurmann, M. and H. Kliemt: 1995, ‘Zur Ökonomie der Tugend,’ Jahrbuch für Politische Ökonomie und Gesellshaft 11, 13-44.

Becker, G. S.: 1976. The Economic Approach to Human Behaviour (University of Chicago Press, Chicago).

--- 1993, ‘The Economic Way of Looking at Behaviour,' Journal of Political Economy 101, 385-409.

--- 1996. Accounting for Tastes (Harvard University Press, Cambridge, Mas.).

Boatright, J. R.: 1996, 'Business Ethics and the Theory of the Firm,' American Business Law Journal 34, 217-238.

--- 2002, 'Contractors as Stakeholders: Reconciling Stakeholder Theory with the Nexus-ofcontracts Firm,' Journal of Banking and Finance 26, 1837-1852.

Brennan, G. and Buchanan, J. M.: 1986. The Reason of Rules. Constitutional Political Economy (Cambridge University Press, Cambridge).

Buchanan, J. M.: 1975. The Limits of Liberty. Between Anarchy and Leviathan (University of Chicago Press, Chicago). 
--- 1987a. Economics: Between Predictive Science and Moral Philosophy (A \& M University Press, College Station, Texas).

--- 1987b, ‘The Constitution of Economic Policy,' American Economic Review 77, 243-50.

--- 1991. The Economics and the Ethics of Constitutional Order (University of Michigan Press, Ann Arbor).

Buono, A. and L. T. Nichols.: 1990, 'Stockholder and Stakeholder. Interpretations of Business' Ethical Role,' in W. M. Hoffman and J. M. Moore (eds.), Business Ethics (McGraw-Hill, New York), $170-75$.

Carroll, A. B.: 1991, ‘The Pyramid of Corporate Social Responsibility: Toward the Moral Management of Corporate Stakeholders,' Business Horizons 34, July-August, 39-48.

Cima, L. R. and T. L. Schubeck.: 2001, 'Self-interest, Love and Economic Justice: A Dialogue Between Classical Economic Liberalism and Catholic Social Teaching.’ Journal of Business Ethics 30(3), 213-31.

Child, J.: 1964, 'Quaker Employers and Industrial Relations,' Sociological Review 12(3), 293313.

Cochran, T. C.: 1957. The American Business System (Harvard University Press, Cambridge, Mas.).

Coleman, J. S.: 1988, 'Social Capital in the Creation of Human Capital,' in C. Winship and S. Rosen (eds.), Organisations and Institutions: Sociological and Economic Approaches to the Analysis of Social Structure, Supplement to the American Journal of Sociology 94, 95-120.

Dran, von, G. M., Gallahan, E. S. and H. V. Taylor: 2001, ‘Can Students’ Academic Integrity Be Improved?,' Teaching Business Ethics 5(1), 35-51.

Dunfee, T. W.: 1998, 'The Marketplace of Morality: First Steps Towards a Theory of Moral Choice,’ Business Ethics Quarterly 8(1), 127-145.

Etzioni, A.: 1988. The Moral Dimension: Towards a New Economics (Free Press, New York). 
Evans, W. M. and R. E. Freeman: 1993, ‘A Stakeholder Theory of the Modern Corporation: Kantian Capitalism,' in G. D. Chryssides and J. H. Kaler (eds.), An Introduction to Business Ethics (Thompson, London), 254-66.

Fort, T. L.: 2000, ‘A Review of Donaldson and Dunfee’s Ties That Bind: A Social Contracts Approach to Business Ethics,' Journal of Business Ethics 28(4), 383-87.

Frank, R. H.: 1996, ‘Can Socially Responsible Firms Survive in a Competitive Environment?’ in D. M. Messick and A. E. Tenbrunsel (eds.), Codes of Conduct: Behavioral Research into Business Ethics (Russell Sage Foundation, New York).

Freeman, R. E.: 1984. Strategic Management: A Stakeholder Approach (Pitman, Boston). Friedman, M.: 1953. Essays in Positive Economics (University of Chicago Press, Chicago). --- 1970, ‘The Social Responsibility of Business is to Increase its Profits,' New York Times Magazine, September 13, 1970.

Gambetta, D.: 1988, ‘Can We Trust Trust?,’ in D. Gambetta (ed.), Trust. Making and Breaking Cooperative Relations (Blackwell: Oxford), 213-37.

Gauthier, D.: 1986. Morals By Agreement (Oxford University Press, Oxford).

Gerecke, U.: 1997. Soziale Ordnung in der modernen Gesellschaft. Doctoral Dissertation (Catholic University of Eichstaett, Ingolstadt).

Good, D.: 1988, 'Individuals, Interpersonal Relations and Trust,' in D. Gambetta (ed.), Trust. Making and Breaking Cooperative Relations (Blackwell, Oxford), 31-48.

Hardin, G.: 1968, 'The Tragedy of the Commons,' Science 162, 1243-48.

Hayek, F.: 1949. Individualism and Economic Order (Routledge, London).

--- 1960. The Constitution of Liberty (Routledge, London).

--- 1976. Law, Legislation and Liberty: The Mirage of Social Justice (Routledge, London).

--- 1979. Law, Legislation and Liberty: The Political Order of a Free People (Routledge, London). 
Hess, D., N. Rogovsky and T. W. Dunfee: 2002, ‘The Next Wave of Corporate Community Involvement: Corporate Social Initiatives,' California Management Review 44(2), 110-125.

Hill, A. and I. Stewart: 1999, 'Character Education in Business Schools: Pedagogical Strategies,' Teaching Business Ethics 3(2), 179-93.

Hirschman, A. O.: 1970. Exit, Voice, and Loyalty (Harvard University Press, Cambridge, Mas.).

Homann, K.: 1990, 'Ökonomik und Ethik.', in Proceedings of the 5th Symposium 'Kirche Heute' October 11-13, Augsburg.

--- 1994, 'Homo oeconomicus und Dilemmastrukturen,' in H. Sautter (ed.), Wirtschaftspolitik in offenen Volkswirtschaften (Vandenhoeck \& Ruprecht, Göttingen), 387-411.

--- 1997, 'Sinn und Grenze der ökonomischen Methode in der Wirtschaftsethik.' Volkswirtschaftliche Schriften 478, 1-42.

Homann, K. and I. Pies: 1991, 'Gefangenendilemma und Wirtschaftsethik,' Wirschaftswissenschaftliches Studium 12, 608-14.

Homann, K. and A. Suchanek: 2000. Ökonomik. Eine Einführung (Mohr-Siebeck, Tübingen). Izzo, G.: 2000, 'Compulsory Ethics Education and the Cognitive Moral Development of Salespeople: A Quasi-Experimental Assessment,' Journal of Business Ethics 28(3), 223-41. Key, S.: 1997, 'Teaching Managers to Respond Ethically to Organisational Crisis,' Teaching Business Ethics 1(2), 197-211.

Küng, H.: 1999, ‘Leitplanken f ür die Moral,’ Der Spiegel, 20.12.1999, 70-3.

Lampe, M.: 1997, 'Increasing the Effectiveness in Teaching Ethics to Undergraduate Business Students,' Teaching Business Ethics 1(1), 3-19.

Luhmann, N.: 1984. Soziale Systeme. Grundriss einer allgemeinen Theorie (Suhrkamp, Frankfurt).

--- 'Familiarity, Confidence, Trust. Problems and Alternatives,' in D. Gambetta (ed.), Trust. Making and Breaking Cooperative Relations (Blackwell, Oxford), 94-107. 
MacIntyre, A.: 1985. After Virtue (Duckworth, London).

Margolis, H.: 1982. Selfishness, Altruism and Rationality (Cambridge University Press, Cambridge).

Moore, G.: 2002, 'On the Implications of the Practice-Institution Distinction: MacIntyre and the Application of Modern Virtue Ethics to Business,' Business Ethics Quarterly 12(1), 19-32.

Moore, G. and A. Robson: 2002, 'The UK Supermarket Industry: An Analysis of Corporate Social and Financial Performance,' Business Ethics. A European Review 11(1), 25-39. Murphy, P. E.: 1998, 'Character and Virtue Ethics in International Marketing: An Agenda for Managers, Researchers and Educators,' Journal of Business Ethics 18(1), 107-24.

North, D. C.: 1993a, 'Institutions and Credible Commitment.' Journal of Institutional and Theoretical Economics 149(1), 11-23.

--- 1993b, 'Institutions and Economic Performance,’ in U. Mäki, B.Gustafsson and C. Knudsen (eds.), Rationality, Institutions and Economic Methodology (Routledge, London), 242-61.

Popper, K.: 1962. The Open Society and Its Enemies: The Spell of Plato (Routledge, London). Preston, D.: 1997, 'Born Again? The Ethics and Efficacy of the Conversion Experience in Contemporary Management Development,' Journal of Management Studies 34(5), 677-701. Sacks, J.: 1999. Morals and Markets (Institute of Economic Affairs IEA, London).

Seshadri, S., Broekemier, G. M. and J. W. Nelson: 1997, 'Business Ethics: To Teach Or Not to Teach?,' Teaching Business Ethics 1(3), 303-313.

Sen, A. K.: 1987. On Ethics and Economics (Blackwell, Oxford).

--- 1990, 'Rational Fools: A Critique of the Behavioural Foundations of Economic Theory,' in Jane J. Mansbridgen (ed.), Beyond Self-interest (University of Chicago Press, Chicago), 2543.

Simon, H. A.: 1945. Administrative Behaviour (The Free Press, New York). 
--- 1993, 'Altruism and Economics,' The American Economic Review. Papers and Proceedings 83(2), $156-61$.

Siu, N. Y, Dickinson, J. R. and B. Y. Lee.: 2000, ‘Ethical Evaluations of Personal Religiousness.’ Teaching Business Ethics 4(3), 239-56.

Smith, A.: 1976. An Inquiry into the Nature and Cause of the Wealth of Nations (Clarendon, Oxford).

Smith, N. C.: 1990. Morality and the Market (New York: Routledge).

Taylor, F. W.: 1964. Scientific Management: Taylor's Testimony Before the Special House Committee (Harper \& Row, London).

Vanberg, V. J.: 1988. Morality and Economics. De Moribus Est Disputandum (Transaction Publishers, Bowling Green).

--- 2001. The Constitution of Markets (Routledge, London).

Wagner, S. A.: 1997. Understanding Green Consumer Behaviour (Routledge, London).

--- 2000, 'The Exodus of the Wealth of Nations.' Working Paper (University of Leicester, Leicester).

Wagner-Tsukamoto, S. A.: 2001a, 'Economics of Genesis: On the Institutional Economic Deciphering and Reconstruction of the Stories of the Bible,' Journal of Interdisciplinary Economics 12(3), 249-86.

--- 2001b, 'The Failure of the Quaker Experiments (1900-1940) in Corporate Social Responsibility: Implications for an Economic Approach to Business Ethics', Proceedings of the EBEN-Conference, 2001, April 9-10, Nottingham.

--- 2003. Human Nature and Organisation Theory. On the Economic Approach to Institutional Organisation (Edward Elgar: Cheltenham).

--- forthcoming, 'An Institutional Economic Reconstruction of Scientific Management: On the Lost Theoretical Logic of Taylorism.’ Academy of Management Review. 
Weber, M.: 1930. The Protestant Ethic and the Spirit of Capitalism (George Allen \& Unwin, London).

Williams, B.: 1985. Ethics and the Limits of Philosophy (Fontana, London).

Williamson, O. E.: 1985. The Economic Institutions of Capitalism (Free Press, New York). 


\section{Endnotes}

${ }^{1}$ In a sense, public order structures of the market economy intentionally create a moral-behavioural dilemma for the firm (Homann and Pies, 1991).

${ }^{2}$ Baurmann and Kliemt (1995) suggest that in the case of relational, long-term contracting, selfinterested behaviour which maximises short-term gain may be prevented if long-term, additional gains can be achieved through less self-interested behaviour. By means of contractual self-binding and/or behavioural self-binding, accompanied and enforced, for instance, by tit-for-tat strategies, moral agency is expected to enter market interactions. (See also Axelrod, 1984; Sacks 1999.) To some extent, this implies that the players of the prisoners' dilemma resolved for themselves the dilemma they are caught up in.

${ }^{3}$ One can speak in this respect of the 'condition of modernity’ (Luhmann, 1984, 1988; Gerecke, 1997).

${ }^{4}$ The success of some small groups, like the Amish people in USA, to preserve a per-modern interaction context in which behavioural ethics can effectively order social interactions is unlikely to provide much encouragement for behavioural (business) ethics research.

${ }^{5}$ Furthermore, political-legal issues of redistributing stockholder property may have to be investigated as well as warnings, e.g. Hayek, that a firm in this way takes on a politically unaccounted for role as moral guardian.

${ }^{6}$ Opportunity costs for obeying moral standards imposed by public ordering may vary among firms. If this is the case, sanctions had to be set at the cost level of the firm with the highest opportunity costs.

${ }^{7}$ Hence, on global markets, international regulation appears necessary for effectively enforcing moral minimum standards through public ordering. WTO agreements can aim at this. Still, negotiations regarding the 'substance' and 'height' of internationally agreed standards are likely to be difficult in view of (1) losses some nations suffer because of tightening regulation, (2) different cultural backgrounds which influence interpretations of what morality should amount to in market interactions, and (3) sanctioning problems in the case agreed standards are violated by one nation.

${ }^{8}$ Dunfee (1998) discussed through the concept of 'passions of propriety' how moral dispositions of individuals who interact with a firm can be approached. Vanberg (1988) or Gauthier (1986) proceeded similarly but more from an economic theoretical perspective. Vanberg, for example, critiqued a Beckerian framework when conceptualising morality as an explanatory variable of economic theory. The present paper, in contrast, focuses on business ethics when conceptualising morality as an explanatory variable of (business) behaviour - and here it is largely compatible with Becker's (1976; 1993; 1996) constraints-based approach to human choice.

${ }^{9}$ Early on Simon's (1945) inducement-contribution analysis referred to customers and the capital market as disciplining influences (on efficiency standards) in an organisation; see also Hirschman (1970); Wagner-Tsukamoto (2003, Sections 2.3, 4.2).

${ }^{10}$ The idea of capital contributions to a firm can be detailed through a concept of 'quasi-property rights', that is rights which are not necessarily legally granted and institutionally protected but primarily rest in economic power, e.g. a pressure group's capability to '(de)-mobilize' a firm's customer base. Also, property rights assessments of ethical capital lead back to systemic considerations of public ordering. As for stock capital, human capital, brand capital, etc public ordering may have to set regulatory standards regarding claims to ethical capital. For instance, initial problems of firms to create and protect ethical capital regarding green products probably reflected that public ordering regarding property rights in 'eco-capital' was inadequate (Wagner, 1997, pp. 3-4). 
The emergence of 'officially' regulated ISO-schemes for assessing the environmental performance of a firm, the certification of fair trading practices, etc. seemingly addresses this issue.

${ }^{11}$ In contrast, Boatright (2002) applies a rights-based approach to questions of stakeholder management and stockholder management. Also, moral issues are neglected in his discussion. Boatright (1996) grounds stakeholder theory in a contractual approach and discusses on this basis business ethics problems for the firm. The concept of ethical capital, as developed in the present paper, specifies certain types of contractual exchanges between firm and stakeholder, namely ones that involve stakeholders who hold both economic assets and ethical preferences.

${ }^{12}$ As already noted earlier, a further qualification applies in relation to transaction cost lowering effects of trust, reciprocity, and so on that is shown in market interactions. 